\title{
Elevated methylation of cyclin dependent kinase inhibitor 2B contributes to the risk of coronary heart disease in women
}

\author{
XIAOMIN CHEN $^{1 *}$, DANJIE JIANG ${ }^{2 *}$, LIMIN XU $^{2 *}$, LIYUAN HAN $^{2}$, HAOCHANG HU ${ }^{1}$, \\ YI HUANG ${ }^{2}$, DEYI LU ${ }^{3}$, HUIHUI JI ${ }^{2}$, BIN LI $^{2}$, YONG YANG ${ }^{2}$, CONG ZHOU $^{2}$, XUTING XU $^{2}$, \\ NAN WU ${ }^{1}$, XIAOFENG XU ${ }^{1}$, YAN XU ${ }^{2}$, YUSHENG SHEN ${ }^{2}$, JIYI LI $^{1}$ and SHIWEI DUAN ${ }^{2}$
}

\begin{abstract}
${ }^{1}$ Key Laboratory of Ningbo First Hospital and Cardiovascular Center of Ningbo First Hospital, Ningbo University, Ningbo, Zhejiang 315010; ${ }^{2}$ Medical Genetics Center, School of Medicine, Ningbo University, Ningbo, Zhejiang 315211, P.R. China;

${ }^{3}$ Richard and Loan Hill Department of Bioengineering, University of Illinois at Chicago, Chicago, IL 60607, USA
\end{abstract}

Received August 7, 2017; Accepted January 18, 2018

DOI: $10.3892 / \mathrm{etm} .2018 .6920$

\begin{abstract}
Cyclin dependent kinase inhibitor 2B (CDKN2B) encodes a cyclin-dependent kinase inhibitor that may enhance the formation of atherosclerotic plaques. The aim of the present study was to investigate the contribution of $C D K N 2 B$ promoter methylation on the risk of coronary heart disease (CHD). The present results indicated a significant association between increased $C D K N 2 B$ methylation and the risk of CHD (adjusted $\mathrm{P}=0.043$ ). A breakdown analysis according to sex demonstrated that $C D K N 2 B$ methylation was significantly associated with the risk of CHD in women (adjusted $\mathrm{P}=0.010$ ), but not in men. A further breakdown analysis by age indicated a significant association of CHD in the women $>60$ years $(\mathrm{P}=0.024)$. Luciferase reporter gene assay results indicated that the $C D K N 2 B$ promoter fragment significantly enhanced luciferase activity $(\mathrm{P}<0.001)$. In addition, $C D K N 2 B$ transcription was significantly enhanced following treatment with 5-aza-2'-deoxycytidine methylation inhibitor in
\end{abstract}

Correspondence to: Dr Xiaomin Chen, Key Laboratory of Ningbo First Hospital and Cardiovascular Center of Ningbo First Hospital, Ningbo University, 59 Liuting Street, Ningbo, Zhejiang 315010, P.R. China

E-mail: chxmin@hotmail.com

Dr Shiwei Duan, Medical Genetics Center, School of Medicine, Ningbo University, 818 Fenghua Road, Ningbo, Zhejiang 315211, P.R. China

E-mail: duashiwei@nbu.edu.cn

*Contributed equally

Abbreviations: CHD, coronary heart disease; DAC, 5-aza-2'-deoxycytidine; GWAS, genome-wide association study; PCR, polymerase chain reaction; HAEC, human aortic endothelial cells; HPCASMC, human primary coronary artery smooth muscle cells

Key words: coronary heart disease, DNA methylation, cyclin dependent kinase inhibitor $2 \mathrm{~B}$, estrogen, cardiovascular drug human aortic endothelial cells (HAEC) and human primary coronary artery smooth muscle cells (HPCASMC; $\mathrm{P}<0.05$ and $\mathrm{P}<0.01$ ), but not in 293 cells. Notably, estrogen treatment reduced $C D K N 2 B$ methylation of several $\mathrm{CpGs}$ and significantly increased $C D K N 2 B$ gene expression levels in HAEC, HPCASMC and 293 cells $(\mathrm{P}<0.05$ and $\mathrm{P}<0.01)$. Additionally, treatment of HAEC and HPCASMC with simvastatin and $\gamma$-carboxy-L-glutamic acid reduced $C D K N 2 B$ promoter methylation and increased $C D K N 2 B$ transcription concomitantly. The present study suggests that $C D K N 2 B$ promoter methylation may be associated with sex dimorphism in the pathogenesis of CHD.

\section{Introduction}

Coronary heart disease (CHD) is the leading cause of mortality in African-American men and women (1). Genetic factors have been demonstrated to serve a significant role in the development of CHD (2). In addition, the involvement of epigenetic modifications has been suggested in the development and the progression of CHD (3-6). DNA methylation is a stable epigenetic modification that results in the addition of a methyl group to the 5 ' carbon of cytosine and primarily occurs at $\mathrm{CpG}$ dinucleotide sequences in the mammalian genome (7). Notably, gene promoter hypermethylation typically silences gene transcription, and aberrant gene methylation has been indicated to be involved in the pathogenesis of various diseases, including CHD $(4,8,9)$ and type 2 diabetes $(10,11)$.

Cyclin dependent kinase inhibitor $2 \mathrm{~B}(C D K N 2 B)$ is located on chromosome 9p21, which has been associated with CHD in a number of genome-wide association studies (GWASs) $(12,13)$. $C D K N 2 B$ encodes a cyclin-dependent kinase inhibitor that regulates cell cycle G1 progression $(14,15)$. Cancer cells with hypermethylated $C D K N 2 B$ are typically associated with aberrantly accelerated proliferation (16). Atherosclerotic plaques are the major contributing factor in CHD pathogenesis and are caused by overproliferation of vascular smooth muscle cells and macrophages $(4,17)$. Notably, $C D K N 2 B$ loss in mice promoted atherosclerosis by increasing the size and complexity of the lipid-laden necrotic core through impaired efferocytosis (17). Furthermore, $C D K N 2 B$ has been suggested 
as a candidate gene of $\mathrm{CHD}(18,19)$. $C D K N 2 B$ hypermethylation has been indicated to be significantly associated with the elevated expression of its antisense noncoding RNA, antisense noncoding RNA in the INK4 locus (ANRIL), and an increased risk of CHD (4). Several studies have revealed the potential roles of $C D K N 2 B$ in CHD $(14,17,20)$.

Sex-specific associations have been indicated in various aspects of CHD. For example, women have been demonstrated to have a proportionally lower prevalence of disease and tend to develop it later in life compared with men, and the difference of incidence, development and surgical treatment of CHD between males and females was indicated in previous studies (21-23). Prior to menopause, women have relatively more protection against CHD compared with men of the same age range (24-26). A previous GWAS indicated sex differences in DNA methylation on 470 autosomal sites, including sites in $C D K N 2 B$ (27). These epigenetic differences are associated with differential mRNA and microRNA expression levels and organ functions (27). In addition, conventional cardiovascular pharmacological agents have been indicated to induce their therapeutic effects on CHD through various mechanisms, for example, by affecting serum levels of vascular calcification inhibitors, which reduce cardiac workload and increase coronary blood flow $(28,29)$.

In the present study, a case-control study was performed to investigate whether $C D K N 2 B$ promoter methylation contributes to the risk of CHD in a sex-dependent pattern, and whether estrogen and conventional cardiovascular pharmacological agents are able to recover $C D K N 2 B$ expression by reversing $C D K N 2 B$ promoter methylation.

\section{Materials and methods}

Samples. CHD and non-CHD control samples were obtained from patients at Ningbo First Hospital (Ningbo, China) between May 2008 and April 2010. A total of 36 CHD cases (18 males and 18 females, mean age, 62.5 \pm 5.5 ) and 36 age- and sex-matched controls were included in the present study. All individuals were Han Chinese from Ningbo city in Eastern China diagnosed according to the World Health Organization criteria (30). The inclusion criteria utilized were as follows: Angiographic evidence of $>50 \%$ stenosis in one or more major coronary arteries. Patients were excluded from the current study if they had congenital heart disease, autoimmune disease, cardiomyopathy or severe liver or kidney disease. All peripheral blood samples from patients $(5 \mathrm{ml})$ were collected in $3.2 \%$ citrate sodium-treated tubes and stored at $-80^{\circ} \mathrm{C}$. The study protocol was approved by the Ethics Committee in Ningbo First Hospital and all methods were performed in accordance with the relevant guidelines and regulations. Written, informed consent forms were obtained from all subjects.

Bisulfite pyrosequencing. Human blood genomic DNA was extracted and quantified as described previously (31). The DNA methylation assay comprised of sodium bisulfite DNA conversion (EpiTech Bisulfite kits; Qiagen AB, Sollentuna, Sweden), polymerase chain reaction (PCR) amplification (Pyromark PCR kit; Qiagen) and pyrosequencing (Pyromark Gold Q24 Reagents; Qiagen $\mathrm{AB}$ ), which were performed in accordance with the manufacturer's protocol. The Pyromark PCR Master Mix was used in PCR amplification. PCR primers were designed using PyroMark Assay Design software v2.0.1.15 (both Qiagen). The sequences of the primers utilized were as follows: $C D K N 2 B$ forward, 5'-TAGGGGGAGGAGTTTAAG GGG-3' and reverse, 5'-biotin-ACACTCTTCCCTTCTTTC C-3'; $C D K N 2 B$ sequencing primer; 5'-GGGGTAGTGAGG ATT-3'. The thermocycling conditions were as follows: 1 cycle at $94^{\circ} \mathrm{C}$ for $15 \mathrm{sex}, 45$ cycles at $94^{\circ} \mathrm{C}$ for $20 \mathrm{sec}, 58^{\circ} \mathrm{C}$ for $30 \mathrm{sec}$, $72^{\circ} \mathrm{C}$ for $60 \mathrm{sec}$ and an extension stage at $72^{\circ} \mathrm{C}$ for $3 \mathrm{~min}$.

Cell lines. Recent studies have suggested that $C D K N 2 B$ is associated with the occurrence and development of several types of cancer $(32,33)$. Notably, 293 cells are typically applied to study the transforming and oncogenic properties of cancer-associated genes as a model (34). Thus, 293 cell lines were selected for the present study. Three cell lines, including 293 cells (https://www.atcc.org/Products/All/CRL-11268. aspx), human aortic endothelial cells (HAEC; https://www. atcc.org/Products/All/PCS-100-011.aspx) and human primary coronary artery smooth muscle cells (HPCASMC; https://www.atcc.org/Products/All/PCS-100-021.aspx) were used in the present study. Cell lines were purchased from American Type Culture Collection (Manassas, VA, USA) and were cultured using dulbecco's modified eagle's medium (DMEM) with 10\% fetal bovine serum (FBS) and penicillin/streptomycin (Invitrogen; Thermo Fisher Scientific, Inc., Waltham, MA, USA) in an incubator at $37^{\circ} \mathrm{C}$ with $5 \% \mathrm{CO}_{2}$ for $24 \mathrm{~h}$.

Treatment with 5-aza-2'-deoxycytidine (DAC), estrogen and cardiovascular pharmacological agents. Cells were cultured at a density of $1 \times 10^{6}$ cells/well in 6-well plates at $37^{\circ} \mathrm{C}$ for $24 \mathrm{~h}$ and the media (DMEM with FBS and penicillin/streptomycin) was replaced following 4-8 h. To determine the potential regulatory roles of DNA methylation in $C D K N 2 B$ gene transcription, HAEC, HPCASMC and 293 cells were treated with DAC (Sigma-Aldrich; Merck $\mathrm{KGaA}$, Darmstadt, Germany) at $0.5,1.0$ and $2.0 \mu \mathrm{M}$ at $37^{\circ} \mathrm{C}$ for 3 days. Following this incubation step, total RNA was isolated from the cells and subjected to reverse transcription. To examine the effects of estrogen treatment, the cells were treated with estrogen (17- $\beta$-estradiol; Sigma-Aldrich; Merck $\mathrm{KGaA})$ at different concentrations $(10,100$ and $1,000 \mathrm{nM})$, and the total RNA and genomic DNA were isolated. In aformentioned comparisons, these three cell lines with the EtOH treatment were considered as the control. In addition, $10 \mu \mathrm{M}$ simvastatin, $10 \mu \mathrm{M}$ trimetazidine dihydrochloride and $50 \mu \mathrm{M} \gamma$-carboxy-L-glutamic acid (all Sigma-Aldrich; Merck $\mathrm{KGaA}$ ) were used to treat HAEC and HPCASMC for 1, 6, 12 and $24 \mathrm{~h}$. Notably, $\gamma$-carboxy-L-glutamic acid is an effective ingredient of isosorbide mononitrate, which is a common cardiovascular drug $(35,36)$. Following treatments, total RNA and genomic DNA were extracted from cells. 293 cells were not subjected to treatment as HAEC and HPCASMC were more specific to cardiovascular disease and thus would produce more meaningful results.

Total RNA extraction and reverse transcription-quantitative PCR (RT-qPCR). TRIzol reagent (Invitrogen; Thermo 
Fisher Scientific, Inc.) was used for total RNA isolation. Subsequently, $1 \mu \mathrm{g}$ RNA was treated with a High Capacity cDNA Reverse Transcription kit (Applied Biosystems, Thermo Fisher Scientific, Inc.) for $2 \mathrm{~h}$ at $37^{\circ} \mathrm{C}$ for cDNA synthesis according to the manufacturer's protocol. qPCR was performed using SYBR green master PCR mix (Applied Biosystems, Thermo Fisher Scientific, Inc.). CDKN2B transcription was normalized to $G A P D H$ transcription levels and the PCR products were quantified using the $2^{-\Delta \Delta C \mathrm{q}}$ method (37). The thermocycling conditions were as follows: denaturation at $94^{\circ} \mathrm{C}$ for $5 \mathrm{~min}$, followed by 40 cycles of amplification (30 sec of denaturation at $94^{\circ} \mathrm{C}, 30 \mathrm{sec}$ of annealing at $58^{\circ} \mathrm{C}$ and $30 \mathrm{sec}$ of extension at $72^{\circ} \mathrm{C}$ ). The following primers were used: $C D K N 2 B$ forward, 5'-GTTAAGTTTACGGCC ACCGG-3' and reverse, 5'-ACCTTCTCCACTAGTCCC-3'; and GAPDH forward, 5'-TGGTATGGAAGGACTCA-3' and reverse, 5'-CCAGTAGAGGCAGGGATGAT-3'.

Bisulfite sequencing. Genomic DNA was isolated from cells with or without estrogen $(10,100$ and $1,000 \mathrm{nM})$ and cardiovascular drug treatments $(10 \mu \mathrm{M}$ simvastatin, $10 \mu \mathrm{M}$ trimetazidine dihydrochloride and $50 \mu \mathrm{M} \gamma$-carboxy-L-glutamic acid) using a genomic DNA isolation kit (Qiagen, Inc., Valencia, CA, USA). Bisulfite conversion reagents (EpiTect Bisulfite kit; Qiagen, Inc.) were used to convert genomic DNA. Products were amplified with the following primers for $C D K N 2 B$ promoter: $C D K N 2 B \_F, 5 '-T T G G T T T A G T T G A A A A Y G G A A$ TT-3'; and $C D K N 2 B \_\mathrm{R}, 5$ '-AACRCCTAACRCRAACRCAAC C-3'. PCR was performed as follows: $95^{\circ} \mathrm{C}$ for $5 \mathrm{~min}$; followed by 35 cycles of $95^{\circ} \mathrm{C}$ for $30 \mathrm{sec}, 52^{\circ} \mathrm{C}$ for $30 \mathrm{sec}, 72^{\circ} \mathrm{C}$ for $30 \mathrm{sec}$, with a final extension of $2 \mathrm{~min}$ at $72^{\circ} \mathrm{C}$. PCR products were cloned using a commercial CloneJET PCR Cloning kit (Thermo Fisher Scientific, Inc.) according to manufacturer's instructions. A total of 15-20 independent bacterial clones were isolated and sequenced for each PCR fragment to calculate the cytosine methylation levels.

Luciferase reporter gene assays. The CDKN2B promoter fragment containing seven $\mathrm{CpG}$ sites was generated using PCR as aforementioned, and the primer sequences of $C D K N 2 B$ were as follows: Forward, 5'-GGGGCAGTG AGGACT-3' and reverse, 5'-GCCTGGATTGCTTCT-3'. The subsequent PCR product was cloned into pCR2.1 (included in the kit) using a T-A Cloning Kit (Invitrogen; Thermo Fisher Scientific, Inc.) and sequenced. Plasmids containing $C D K N 2 B$ promoter region were amplified and digested with XhoI and KpnI (New England Biolabs, Ipswich, MA, USA). The target DNA fragment containing the reporter gene was cloned into pGL3-Luciferase reporter plasmid (Promega Corporation, Madison, WI, USA). Subsequently, constructed pGL3-CDKN2B-Luciferase plasmid was transfected into 293 cells using Lipofectamine 2000 Reagent (Invitrogen; Thermo Fisher Scientific, Inc.) according to manufacturer's protocol. A total of $24 \mathrm{~h}$ following transfection, cells were lysed with Tropix lysis buffer (Applied Biosystems; Thermo Fisher Scientific, Inc.). Luciferase and $\beta$-galactosidase activities were measured using a Luciferase Assay System (Applied Biosystems; Thermo Fisher Scientific, Inc.) according to manufacturer's protocol. $\beta$-Galactosidase activity was used to normalize transfection efficiency.
Statistical analysis. SPSS package software (version 16.0; SPSS, Inc., Chicago, IL, USA) was used to determine the association between $C D K N 2 B$ promoter methylation with $\mathrm{CHD}$ and various biochemical factors. Comparisons of $C D K N 2 B$ methylation were performed using GraphPad Prism 5 Software (GraphPad Software, Inc., La Jolla, CA, USA). Correlations of $C D K N 2 B$ methylation with age and biochemical indicators were performed using R statistical software (R V.3.3.2; https://www.r-project. org/). All P-values were adjusted for age, smoking, diabetes and hypertension. Relative expression data were presented as the mean \pm standard deviation. Statistical analysis for RT-qPCR data was performed using one-way analysis of variance followed by a Dunnett's post hoc test. $\mathrm{P}<0.05$ was considered to indicate a statistically significant difference.

\section{Results}

Significant association of CDKN2B promoter methylation with $C H D$ in women. The bisulfite pyrosequencing assay was used to measure a total of seven CpGs on the $C D K N 2 B$ promoter among 36 cases and 36 matched controls. Significant correlations were observed among DNA methylation levels of seven CpGs (r>0.7, Fig. 1A). Subsequently $C D K N 2 B$ methylation was represented as the mean methylation level of the seven CpGs. As indicated in Table I and Fig. 1B, significantly increased $C D K N 2 B$ methylation levels $(7.66 \pm 3.02 \%)$ were observed in patients with $\mathrm{CHD}$ compared with non-CHD subjects $(6.43 \pm 2.23 \%$, adjusted $\mathrm{P}=0.043)$. In addition, a significant association of CHD with sex was indicated regarding $C D K N 2 B$ methylation (adjusted $\mathrm{P}=0.048$; Fig. 1B). Further analysis demonstrated a significant female-specific association of $C D K N 2 B$ methylation with $\mathrm{CHD}$ [women with CHD (7.21 $\pm 2.40 \%)$ compared with women without CHD $(4.83 \pm 1.31 \%)$, adjusted $\mathrm{P}=0.010$; Fig. $1 \mathrm{~B}]$. However, there was no significant correlation between $C D K N 2 B$ methylation and age in the whole cohort (total, $\mathrm{r}=0.041$, adjusted $\mathrm{P}=0.811$; Fig. 1C), further analysis regarding age indicated a significant association with CHD in women $>60$ years old (women, $\mathrm{r}=0.672$, adjusted $\mathrm{P}=0.024$; Fig. $1 \mathrm{C}$ ).

CDKN2B promoter fragment enhances luciferase gene activity. The dual-luciferase reporter assay is a standard method that utilizes Firefly and Renilla luciferase to explore the promoter activity of target fragment (38). The $C D K N 2 B$ promoter fragment containing seven $\mathrm{CpG}$ sites was amplified and cloned into pGL3 luciferase plasmid in the present study. The construct was transfected into 293 cells. Notably, HPCASMC and HAEC were difficult transfect and were therefore excluded from this experiment. Results suggested that the $C D K N 2 B$ promoter fragment significantly enhanced the luciferase activity by $>200$ fold compared with pGL3-Basic in 293 cells $(\mathrm{P}<0.001$; Fig. 2A). The present results indicated that $C D K N 2 B$ promoter enhanced the luciferase activity in 293 cells.

Methylation inhibitor DAC enhances CDKN2B gene transcription. Endogenous $C D K N 2 B$ transcription levels were determined in HPCASMC, HAEC and 293 cells (Fig. 2B). Furthermore, cell lines were incubated with different concentrations of DAC, a DNA methyltransferase 
Table I. Comparison of cyclin dependent kinase inhibitor 2B methylation levels within subgroups.

\begin{tabular}{|c|c|c|c|c|}
\hline \multirow[b]{2}{*}{ Variable } & \multicolumn{2}{|c|}{ DNA methylation (\%) } & \multirow[b]{2}{*}{ P-value } & \multirow[b]{2}{*}{$\begin{array}{c}\text { Sex subgroup } \\
\text { interaction P-value }\end{array}$} \\
\hline & $\begin{array}{c}\mathrm{CHD}(\mathrm{n}=36) \\
\text { mean } \pm \mathrm{SD}\end{array}$ & $\begin{array}{c}\text { Non-CHD } \\
(n=36) \text { mean } \pm \text { SD }\end{array}$ & & \\
\hline \multicolumn{5}{|l|}{ DNA methylation site } \\
\hline CpG 1 & $8.89 \pm 3.97$ & $7.44 \pm 2.99$ & 0.066 & 0.058 \\
\hline CpG 2 & $5.94 \pm 2.03$ & $5.14 \pm 1.78$ & 0.042 & 0.239 \\
\hline CpG 3 & $6.11 \pm 2.81$ & $4.61 \pm 1.68$ & 0.012 & 0.088 \\
\hline $\mathrm{CpG} 4$ & $4.83 \pm 2.25$ & $4.00 \pm 1.64$ & 0.057 & 0.168 \\
\hline CpG 5 & $9.19 \pm 4.03$ & $7.97 \pm 3.07$ & 0.149 & 0.278 \\
\hline CpG 6 & $9.03 \pm 3.19$ & $8.11 \pm 2.97$ & 0.142 & 0.005 \\
\hline CpG 7 & $9.61 \pm 4.09$ & $7.72 \pm 3.53$ & 0.031 & 0.023 \\
\hline Mean \pm SD DNA methylation (\%) & $7.66 \pm 3.02$ & $6.43 \pm 2.23$ & 0.043 & 0.048 \\
\hline
\end{tabular}

P-values were adjusted by age, history of smoking, diabetes and hypertension. CHD, coronary heart disease; SD, standard deviation.
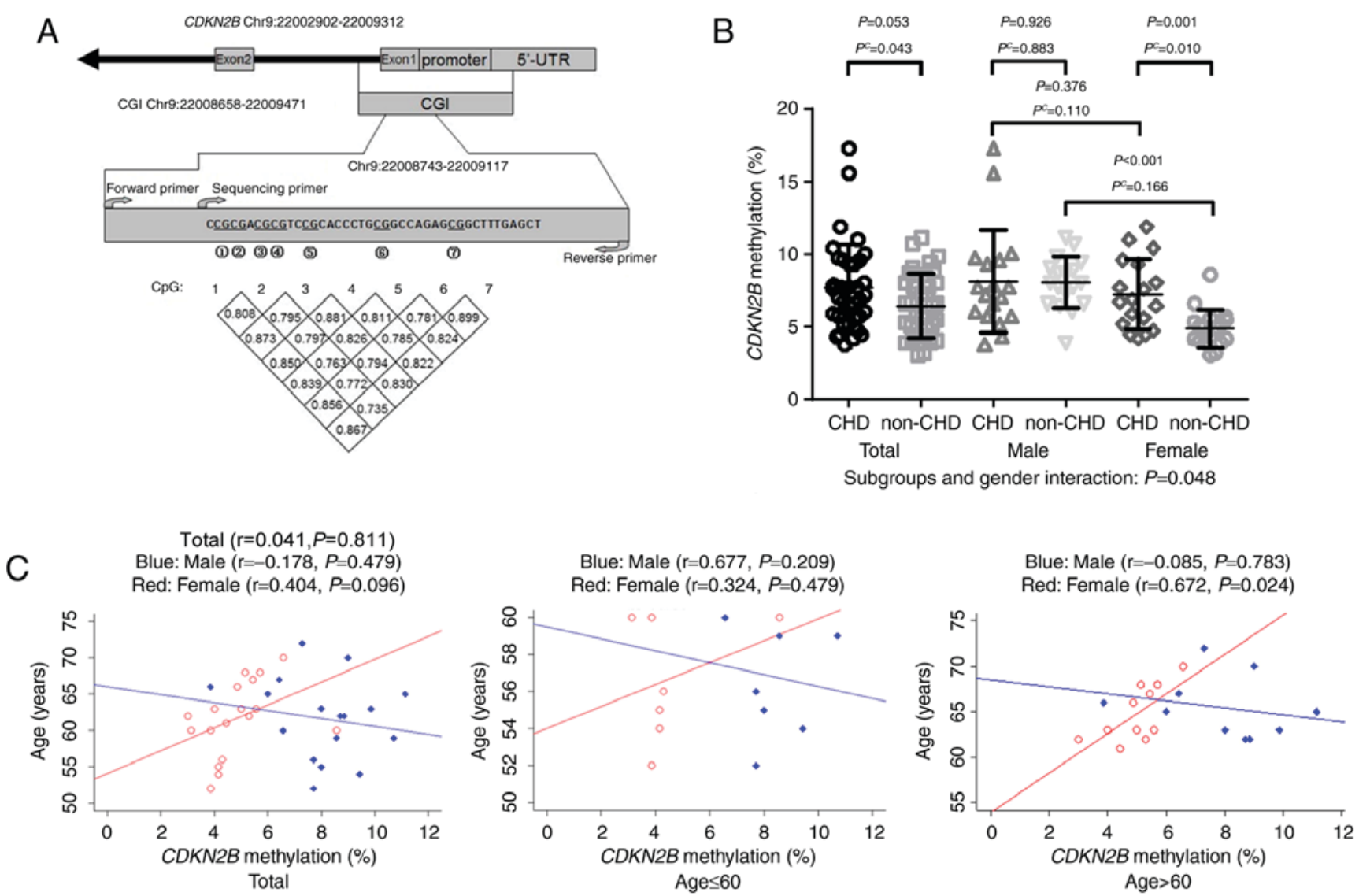

Figure 1. Sex dimorphism in the association of $C D K N 2 B$ promoter methylation with CHD and age. (A) Significant association among the seven $C D K N 2 B$ promoter CpGs. All r-values are presented in the squares (all $\mathrm{P}<0.05$ ). (B) Significant differences of $C D K N 2 B$ methylation between CHD and non-CHD subjects. (C) Correlation between $C D K N 2 B$ promoter methylation and age. $\mathrm{P}^{\mathrm{c}}$, $\mathrm{P}$-value adjusted according to age, history of smoking, diabetes and hypertension. CHD, coronary heart disease; CDKN2B, cyclin dependent kinase inhibitor 2B.

inhibitor. Results revealed that DAC $(0.5 \mu \mathrm{M} / \mathrm{l})$ significantly upregulated $C D K N 2 B$ transcription levels compared with EtOH treatment in HPCASMC $(\mathrm{P}<0.05 ;$ Fig. $2 \mathrm{C})$. In addition, DAC $(1 \mu \mathrm{M} / 1$ and $2 \mu \mathrm{M} / 1)$ significantly upregulated $C D K N 2 B$ transcription levels compared with EtOH in HAEC $(1 \mu \mathrm{M} / 1$, $\mathrm{P}<0.01$ and $2 \mu \mathrm{M} / 1, \mathrm{P}<0.01$; Fig. $2 \mathrm{C})$. However, no significant differences in $C D K N 2 B$ transcription levels were detected in 293 cells, which may have been due to the high endogenous $C D K N 2 B$ expression. In light of these findings, it was speculated that DNA methylation may serve an important role in the regulation of $C D K N 2 B$ transcription in HAEC and HPCASMC 
A
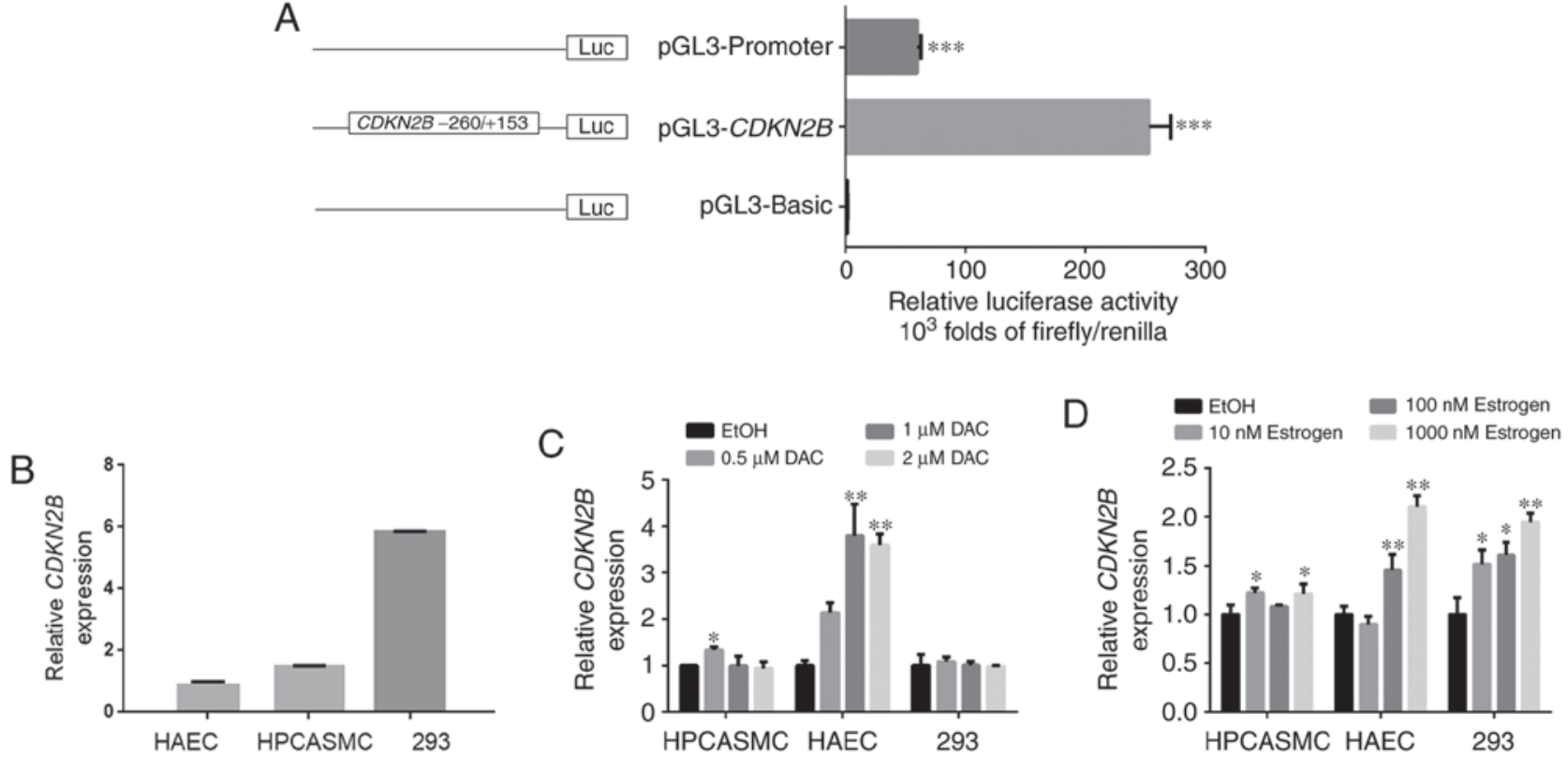

Figure 2. Relative transcription levels of $C D K N 2 B$ in HPCASMC, HAEC and 293 cells. (A) Relative luciferase activity in the 293 cell lines. ${ }^{* * *} \mathrm{P}<0.001$ (pGL3-Promoter vs. pGL3-Basic and pGL3-CDKN2B vs. pGL3-Basic). (B) Endogenous $C D K N 2 B$ transcription levels in the cell lines. The expression level of HAEC was presumed as the basic value. The relative expression value was calculated as the expression levels of cells divided by the basic value. (C) Relative transcription of $C D K N 2 B$ in the cell lines treated with DAC. (D) Relative transcription of $C D K N 2 B$ in the cell lines treated with estrogen. ${ }^{*}<0.05$ (treatment with estrogen vs. treatment with EtOH); ${ }^{* *} \mathrm{P}<0.01$ (treatment with estrogen vs. treatment with EtOH). The expression levels of cells treated with EtOH were considered as the basic value in same cell line. CDKN2B, cyclin dependent kinase inhibitor 2B; HAEC, human aortic endothelial cells; HPCASMC, human primary coronary artery smooth muscle cells; EtOH, ethanol; DAC, 5-aza-2'-deoxycytidine.

Estrogen increases $C D K N 2 B$ transcription and alters its promoter methylation. Cells were incubated with different concentrations of estrogen. Results suggested that estrogen significantly upregulated $C D K N 2 B$ transcription levels in HAEC and 293 cells compared with EtOH treatment (HAEC, $100 \mathrm{nM} / \mathrm{l}: \mathrm{P}<0.01$ and $1,000 \mathrm{nM} / \mathrm{l}: \mathrm{P}<0.01 ; 293,10 \mathrm{nM} / 1$ : $\mathrm{P}<0.05,100 \mathrm{nM} / \mathrm{l}: \mathrm{P}<0.05$ and 1,000 nM/l: $\mathrm{P}<0.01$; Fig. 2D). Specific concentrations of estrogen also significantly increased $C D K N 2 B$ transcription levels in HPCASMC (HPCASMC, $10 \mathrm{nM} / \mathrm{l}: \mathrm{P}=0.015$ and $1,000 \mathrm{nM} / \mathrm{l}: \mathrm{P}=0.030$; Fig. 2D).

Methylation levels of seven $C D K N 2 B$ CpGs were varied in HAEC, HPCASMC and 293 cells. There were four fully methylated CpGs (CpG-1, 5, 6 and 7) and three unmethylated CpGs (CpG-2, 3 and 4) in 293 cells, and four fully methylated CpGs (CpG-1, 2, 3 and 6) and three unmethylated CpGs (CpG-4, 5 and 7) in HPCASMC. The methylation levels of the seven CpGs were <0.3 in HAEC (Fig. 3). In some cases, estrogen treatment reduced the methylation levels of previously hypermethylated CpGs and increased the methylation levels of previously hypomethylated CpGs in HPCASMC and 293 cells (Fig. 3). Notably, estrogen treatment was able to increase the methylation levels of the majority of CpG sites in HAEC.

Although estrogen treatment did not result in a similar methylation pattern among the three cell lines, the results suggested that estrogen was able to increase $C D K N 2 B$ gene transcription among the three cell lines. The findings indicated that estrogen may increase $C D K N 2 B$ transcription by altering $C D K N 2 B$ methylation.

Cardiovascular pharmacological agents increase CDKN2B transcription and reduce $C D K N 2 B$ promoter methylation concomitantly. Three cardiovascular pharmacological agents, including simvastatin, $\gamma$-carboxy-L-glutamic acid and trimetazidine dihydrochloride, were selected to explore their regulatory effects on $C D K N 2 B$. Results revealed that 24-h treatment with these agents significantly altered $C D K N 2 B$ transcription levels in HPCASMC and HAEC, with the exception of HAEC treated with simvastatin and $\gamma$-carboxy-L-glutamic acid $(\mathrm{P}<0.05$ and $\mathrm{P}<0.01$; Fig. 4A). Notably, $C D K N 2 B$ transcription levels in HPCASMC increased 63.3-fold following $24 \mathrm{~h}$ treatment with simvastatin, 26.5-fold following $24 \mathrm{~h}$ treatment with $\gamma$-carboxy-L-glutamic acid and 41.9-fold following $24 \mathrm{~h}$ treatment with trimetazidine dihydrochloride, respectively (Fig. 4A). CDKN2B transcription levels in HAEC increased 2.0-fold following $12 \mathrm{~h}$ treatment with simvastatin and 40.0-fold following $6 \mathrm{~h}$ treatment with $\gamma$-carboxy-L-glutamic acid treatment, respectively (Fig. 4A). Conversely, CDKN2B transcription levels significantly decreased 2.2-fold following $24 \mathrm{~h}$ trimetazidine dihydrochloride treatment in HAEC $(\mathrm{P}<0.01$; Fig. 4A). Methylation assays demonstrated that the cardiovascular pharmacological agents reduced $C D K N 2 B$ methylation levels in HAEC and HPCASMC (Fig. 4B). Treatment with simvastatin, $\gamma$-carboxy-L-glutamic acid and trimetazidine dihydrochloride reduced $C D K N 2 B$ promoter methylation and increased $C D K N 2 B$ transcription concomitantly in HPCASMC. Additionally, treatment with simvastatin and $\gamma$-carboxy-L-glutamic acid reduced $C D K N 2 B$ promoter methylation and increased $C D K N 2 B$ transcription concomitantly in HAEC.

\section{Discussion}

In the present study, it was identified that there was a female-specific association of elevated $C D K N 2 B$ promoter 


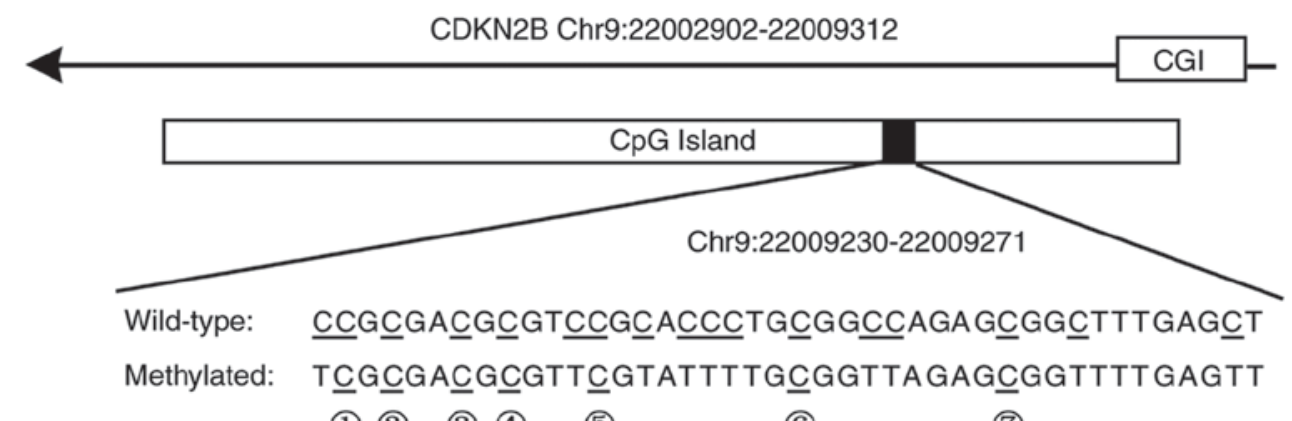
(1) (2)
(3) (4)
(5)
(6)
(7)
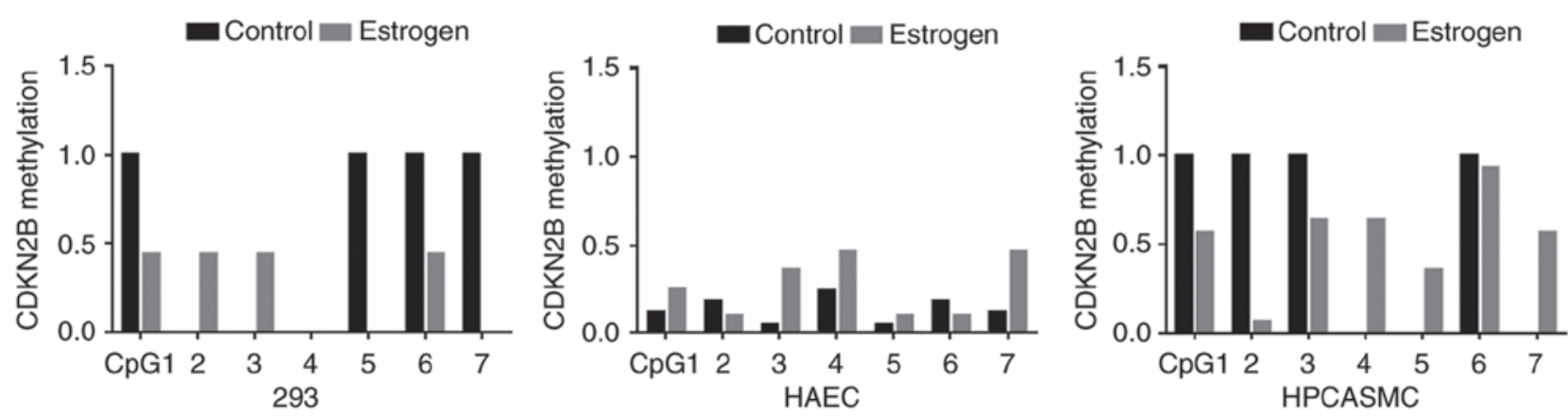

Figure 3. Methylation levels of $C D K N 2 B$ in HPCASMC, HAEC and 293 cells treated with estrogen. The cells treated with EtOH were used as the control. CDKN2B, cyclin dependent kinase inhibitor 2B; HAEC, human aortic endothelial cells; HPCASMC, human primary coronary artery smooth muscle cells.

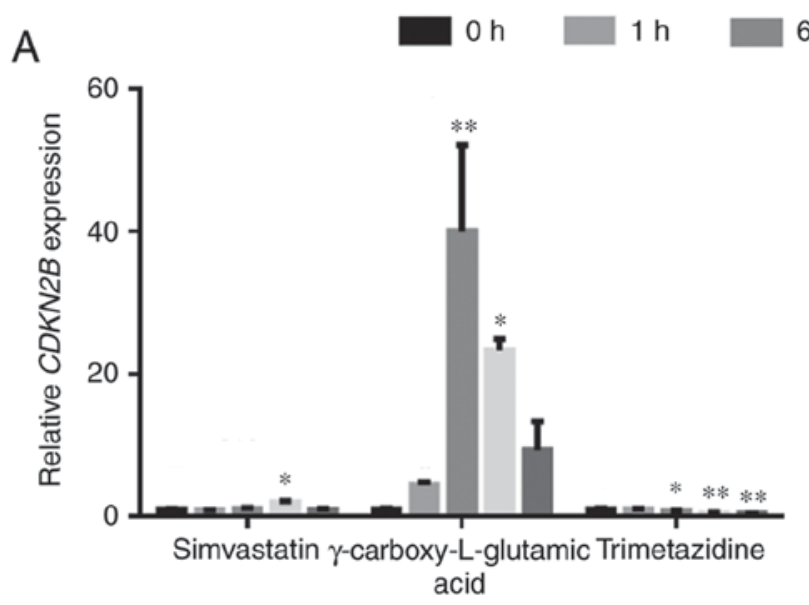

HAEC

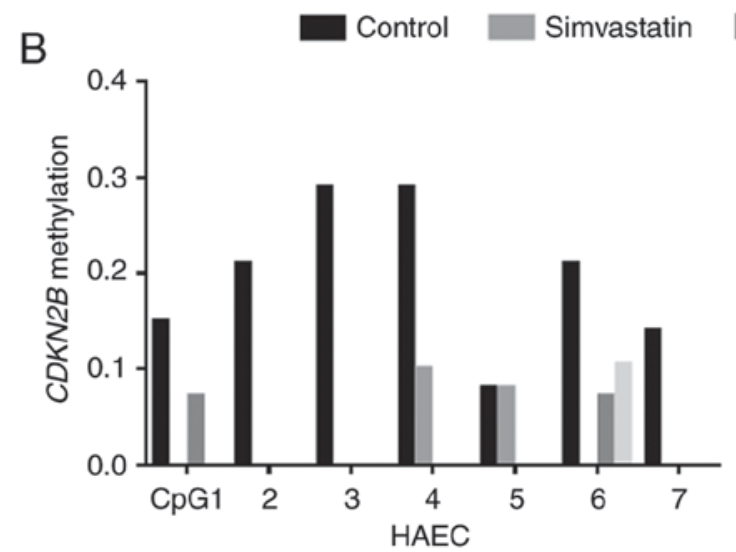

$6 \mathrm{~h}$

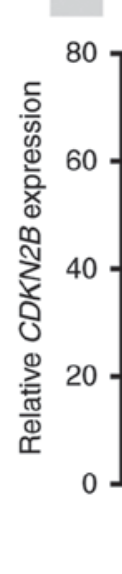

Trimetazidine
$24 \mathrm{~h}$

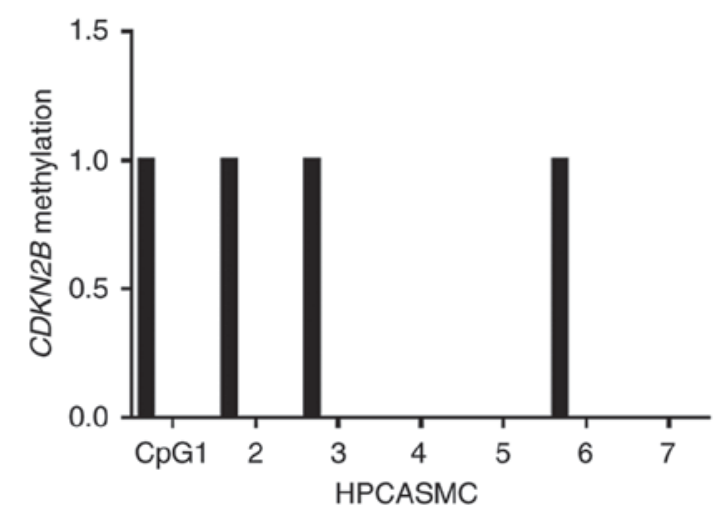

Figure 4. Methylation and relative transcription levels of $C D K N 2 B$ in HPCASMC and HAEC treated with simvastatin, trimetazidine dihydrochloride and $\gamma$-carboxy-L-glutamic acid. (A) Relative $C D K N 2 B$ transcription levels in the cell lines treated with the three cardiovascular pharmacological agents at 0,1 , 6, 12 and $24 \mathrm{~h} .{ }^{*} \mathrm{P}<0.05,{ }^{* *} \mathrm{P}<0.01$. (B) Methylation levels of $C D K N 2 B$ CpGs in the cell lines treated with the three cardiovascular pharmacological agents. Cell lines with the EtOH treatment were considered as the control. CDKN2B, cyclin dependent kinase inhibitor 2B; HAEC, human aortic endothelial cells; HPCASMC, human primary coronary artery smooth muscle cells. 
methylation with CHD. Subsequent functional experiments indicated that $C D K N 2 B$ promoter methylation is important for gene expression, which was further demonstrated to be susceptible to estrogen and conventional cardiovascular pharmacological agents.

$C D K N 2 B$ has been suggested to regulate efferocytosis and atherosclerosis (39). The deletion of $C D K N 2 B$ promotes the advanced development of atherosclerotic plaques (40). Furthermore, $C D K N 2 B$ expression is reduced in atherosclerotic plaques, indicating that $C D K N 2 B$ serves an essential role in the formation of atherosclerotic plaques (39). In the present study, the $C D K N 2 B$ promoter fragment was able to significantly enhance luciferase reporter gene activity. Furthermore, methylation inhibitor DAC increased $C D K N 2 B$ transcription levels. These results suggest that $C D K N 2 B$ promoter methylation may be important in the regulation of $C D K N 2 B$ gene function.

Sex dimorphism of CHD has been observed in the prevalence and the onset age of CHD $(21,41)$. Notably, the onset age of CHD in women is typically 10 years later than that in men (21). Furthermore, non-obstructive CHD and angina are more frequently identified in women than in men $(42,43)$. Previous results suggested an interaction between sex and age impacted DNA methylation $(44,45)$. Furthermore, age has been indicated to increase the risk of CHD in women compared with men (46). CHD risk in men plateaus at the age of 45-50, whereas in women, CHD risk continues to increase sharply until the age of 60-65 (47). In the present study, a female-specific association of elevated $C D K N 2 B$ promoter methylation was indicated with the risk of CHD. Further analysis by age suggested that the women $>60$ years of age had significantly higher $C D K N 2 B$ promoter methylation levels.

Studies have indicated that estrogen may inhibit atherosclerotic plaque progression and vasodilation through its anti-oxidative and anti-inflammatory properties $(21,43,48)$. Furthermore, it has been identified that estrogen may influence neoplastic diseases via its effects on the levels of gene expression and DNA methylation $(49,50)$. In the present study, $C D K N 2 B$ transcription levels were upregulated following estrogen treatment in HPCASMC, HAEC and 293 cells, in addition with promoter cytosine modifications in the promoter region of $C D K N 2 B$. The present findings suggest that estrogen may exert its regulatory role through promoter methylation modification.

Cardiovascular pharmacological agents include angiotensin-converting enzyme inhibitors, nitrates, statins and $\beta$-adrenergic blockers (51-54). Abnormal gene methylation may influence the curative effect of various kinds of drugs, including anti-tumor drugs and chemotherapeutic drugs (55-57). In the present study, treatment with three types of cardiovascular pharmacological agents increased $C D K N 2 B$ transcription levels and reduced $C D K N 2 B$ methylation levels concomitantly in HPCASMC. Similar results were identified in $\mathrm{HAEC}$, except trimetazidine was demonstrated to decrease $C D K N 2 B$ transcription in HAEC and further study should be performed to verify this result. This suggests that these agents may deliver their effects through $C D K N 2 B$ gene silencing.

In conclusion, the present study demonstrated the role of DNA methylation in the regulation of $C D K N 2 B$ transcription and that $C D K N 2 B$ transcription may be affected by estrogen and cardiovascular pharmacological agents. Furthermore, the present results provided an improved understanding of the mechanisms by which $C D K N 2 B$ may contribute to the risk of CHD in women. Due to the moderate sample size, future studies with extended samples are required to assess the significant association of $C D K N 2 B$ promoter methylation with CHD in females.

\section{Acknowledgements}

Not applicable.

\section{Funding}

The present study was supported by grants from the National Natural Science Foundation of China (grant no. 81371469), the Natural Science Foundation of Zhejiang Province (grant no. LR13H020003) and from K. C. Wong Magna Fund in Ningbo University (Ningbo, Zhejiang, China).

\section{Availability of data and materials}

The datasets used and/or analyzed during the current study are available from the corresponding author on reasonable request.

\section{Authors' contributions}

$\mathrm{XC}$ and SD conceived and designed the current study. YY, HJ, CZ, BL, XuX, XiX, NW, YX, JL and YS performed the experiments. DJ, LX, LH, YH, DL and YX performed the analyses. $\mathrm{XC}, \mathrm{DJ}, \mathrm{LX}$ and $\mathrm{HH}$ prepared all figures and tables. XC wrote the manuscript. All the authors reviewed the manuscript and agreed to its publication.

\section{Ethics approval and consent to participate}

The protocol of the current study was approved by the Ethics Committee of Ningbo First Hospital (Ningbo, China) and all methods were performed in accordance with the relevant guidelines and regulations.

\section{Patient consent for publication}

Written informed consent was obtained from all patients.

\section{Competing interests}

The authors declare that they have no competing interests.

\section{References}

1. Lettre G,Palmer CD, Young T, Ejebe KG, Allayee H, Benjamin EJ, Bennett F, Bowden DW, Chakravarti A, Dreisbach A, et al: Genome-wide association study of coronary heart disease and its risk factors in 8,090 African Americans: The NHLBI CARe Project. PLoS Genet 7: e1001300, 2011.

2. Katzmarzyk PT, Perusse L, Rice T, Gagnon J, Skinner JS, Wilmore JH, Leon AS, Rao DC and Bouchard C: Familial resemblance for coronary heart disease risk: The HERITAGE family study. Ethn Dis 10: 138-147, 2000. 
3. Loscalzo J and Handy DE: Epigenetic modifications: Basic mechanisms and role in cardiovascular disease (2013 Grover Conference series). Pulm Circ 4: 169-174, 2014.

4. Zhuang J, Peng W, Li H, Wang W, Wei Y, Li W and Xu Y: Methylation of p15INK4b and expression of ANRIL on chromosome 9p21 are associated with coronary artery disease. PLoS One 7: e47193, 2012.

5. Baccarelli A, Rienstra M and Benjamin EJ: Cardiovascular epigenetics: Basic concepts and results from animal and human studies. Circ Cardiovasc Genet 3: 567-573, 2010.

6. Turunen MP, Aavik E and Ylä-Herttuala S: Epigenetics and atherosclerosis. Biochim Biophys Acta 1790: 886-891, 2009.

7. Feinberg AP: Phenotypic plasticity and the epigenetics of human disease. Nature 447: 433-440, 2007.

8. Friso S, Lotto V, Choi SW, Girelli D, Pinotti M, Guarini P, Udali S, Pattini P, Pizzolo F, Martinelli N, et al: Promoter methylation in coagulation F7 gene influences plasma FVII concentrations and relates to coronary artery disease. J Med Genet 49: 192-199, 2012.

9. Guay SP, Brisson D, Munger J, Lamarche B, Gaudet D and Bouchard L: ABCA1 gene promoter DNA methylation is associated with HDL particle profile and coronary artery disease in familial hypercholesterolemia. Epigenetics 7: 464-472, 2012.

10. Dayeh TA, Olsson AH, Volkov P, Almgren P, Ronn T and Ling C: Identification of CpG-SNPs associated with type 2 diabetes and differential DNA methylation in human pancreatic islets. Diabetologia 56: 1036-1046, 2013.

11. Yang M, Sun JZ, Sun YL, You W, Dai J and Li GS: Association between leptin gene promoter methylation and type 2 diabetes mellitus. Zhonghua Yi Xue Yi Chuan Xue Za Zhi 29: 474-477, 2012 (In Chinese).

12. Samani NJ, Erdmann J, Hall AS, Hengstenberg C, Mangino M, Mayer B, Dixon RJ, Meitinger T, Braund P, Wichmann HE, et al: Genomewide association analysis of coronary artery disease. $\mathrm{N}$ Eng J Med 357: 443-453, 2007.

13. Wellcome Trust Case Control Consortium: Genome-wide association study of 14,000 cases of seven common diseases and 3,000 shared controls. Nature 447: 661-678, 2007.

14. Pilbrow AP, Folkersen L, Pearson JF, Brown CM, McNoe L, Wang NM, Sweet WE, Tang WH, Black MA, Troughton RW, et al: The chromosome 9p21.3 coronary heart disease risk allele is associated with altered gene expression in normal heart and vascular tissues. PLoS One 7: e39574, 2012.

15. Soto JL, Cabrera CM, Serrano S and López-Nevot MA: Mutation analysis of genes that control the G1/S cell cycle in melanoma: TP53, CDKN1A, CDKN2A, and CDKN2B. BMC Cancer 5: 36 , 2005.

16. Herman JG and Baylin SB: Gene silencing in cancer in association with promoter hypermethylation. N Eng J Med 349: 2042-2054, 2003.

17. Motterle A, Pu X, Wood H, Xiao Q, Gor S, Ng FL, Chan K, Cross F Shohreh B, Poston RN, et al: Functional analyses of coronary artery disease associated variation on chromosome 9p21 in vascular smooth muscle cells. Hum Mol Genet 21: 4021-4029, 2012.

18. McPherson R, Pertsemlidis A, Kavaslar N, Stewart A, Roberts R, Cox DR, Hinds DA, Pennacchio LA, Tybjaerg-Hansen A, Folsom AR, et al: A common allele on chromosome 9 associated with coronary heart disease. Science 316: 1488-1491, 2007.

19. Helgadottir A, Thorleifsson G, Manolescu A, Gretarsdottir S, Blondal T, Jonasdottir A, Jonasdottir A, Sigurdsson A, Baker A, Palsson A, et al: A common variant on chromosome 9 p21 affects the risk of myocardial infarction. Science 316: 1491-1493, 2007.

20. Jarinova O, Stewart AF, Roberts R, Wells G, Lau P, Naing T, Buerki C, McLean BW, Cook RC, Parker JS and McPherson R: Functional analysis of the chromosome 9p21.3 coronary artery disease risk locus. Arterioscler Thromb Vasc Biol 29: 1671-1677, 2009.

21. Lawton JS: Sex and gender differences in coronary artery disease. Semin Thorac Cardiovasc Surg 23: 126-130, 2011.

22. Sbarouni E, Georgiadou P and Voudris V: Gender-specific differences in biomarkers responses to acute coronary syndromes and revascularization procedures. Biomarkers 16: 457-465, 2011.

23. Hu G, Jousilahti P, Qiao Q, Peltonen M, Katoh S and Tuomilehto J: The gender-specific impact of diabetes and myocardial infarction at baseline and during follow-up on mortality from all causes and coronary heart disease. J Am Coll Cardiol 45: 1413-1418, 2005.

24. Post WS, Goldschmidt-Clermont PJ, Wilhide CC, Heldman AW, Sussman MS, Ouyang P, Milliken EE and Issa JP: Methylation of the estrogen receptor gene is associated with aging and atherosclerosis in the cardiovascular system. Cardiovasc Res 43: 985-991, 1999
25. Barrett-Connor E and Bush TL: Estrogen and coronary heart disease in women. JAMA 265: 1861-1867, 1991

26. Kannel WB, Hjortland MC, McNamara PM and Gordon T: Menopause and risk of cardiovascular disease: The Framingham study. Ann Intern Med 85: 447-452, 1976.

27. Hall E, Volkov P, Dayeh T, Esguerra JL, Salö S, Eliasson L, Rönn T, Bacos K and Ling C: Sex differences in the genome-wide DNA methylation pattern and impact on gene expression, microRNA levels and insulin secretion in human pancreatic islets. Genome Biol 15: 522, 2014.

28. Kadoglou NP, Kottas G, Lampropoulos S, Vitta I and Liapis CD: Serum levels of fetuin-A, osteoprotegerin and osteopontin in patients with coronary artery disease: Effects of statin (HMGCoA-reductase inhibitor) therapy. Clin Drug Invest 34: 165-171, 2014.

29. Cross HR: Trimetazidine for stable angina pectoris. Exp Opin Pharmacother 2: 857-875, 2001.

30. Ni W, Zhou Z, Liu T, Wang H, Deng J, Liu X and Xing G: Gender-and lesion number-dependent difference in 'atherogenic index of plasma' in Chinese people with coronary heart disease. Sci Rep 7: 13207, 2017.

31. Zhou J, Huang Y, Huang RS, Wang F, Xu L, Le Y, Yang X, Xu W, Huang $X$, Lian J and Duan S: A case-control study provides evidence of association for a common SNP rs974819 in PDGFD to coronary heart disease and suggests a sex-dependent effect. Thromb Res 130: 602-606, 2012.

32. Tu Q, Hao J, Zhou X, Yan L, Dai H, Sun B, Yang D, An S, Lv L, Jiao B, et al: CDKN2B deletion is essential for pancreatic cancer development instead of unmeaningful co-deletion due to juxtaposition to CDKN2A. Oncogene 37: 128-138, 2018.

33. Li Y, Chen M, Liu J, Li L, Yang X, Zhao J, Wu M and Ye M: Upregulation of MicroRNA $18 \mathrm{~b}$ contributes to the development of colorectal cancer by inhibiting CDKN2B. Mol Cell Biol 37: 2017.

34. Stepanenko AA and Dmitrenko VV: HEK293 in cell biology and cancer research: Phenotype, karyotype, tumorigenicity, and stress-induced genome-phenotype evolution. Gene 569: 182-190, 2015.

35. Burnier JP, Borowski M, Furie BC and Furie B: Gamma-carboxyglutamic acid. Mol Cell Biochem 39: 191-207, 1981.

36. Deyl Z, Macek K, Vancikova O and Adam M: The presence of gamma-carboxyglutamic acid-containing protein in atheromatous aortae. Biochim Biophys Acta 581: 307-315, 1979.

37. Livak KJ and Schmittgen TD: Analysis of relative gene expression data using real-time quantitative PCR and the 2(-Delta Delta C(T)) method. Methods 25: 402-408, 2001

38. Xu YZ, Kanagaratham C, Jancik S and Radzioch D: Promoter deletion analysis using a dual-luciferase reporter system. Methods Mol Biol 977: 79-93, 2013.

39. Kojima Y, Downing K, Kundu R, Miller C, Dewey F, Lancero H, Raaz U, Perisic L, Hedin U, Schadt E, et al: Cyclin-dependent kinase inhibitor $2 \mathrm{~B}$ regulates efferocytosis and atherosclerosis. J Clin Invest 124: 1083-1097, 2014.

40. Svensson PA, Wahlstrand B, Olsson M, Froguel P, Falchi M, Bergman RN, McTernan PG, Hedner T, Carlsson LM and Jacobson P: CDKN2B expression and subcutaneous adipose tissue expandability: Possible influence of the 9p21 atherosclerosis locus. Biochem Biophys Res Commun 446: 1126-1131, 2014.

41. Zhong J, Chen X, Ye H, Wu N, Chen X and Duan S: CDKN2A and CDKN2B methylation in coronary heart disease cases and controls. Exp Ther Med 14: 6093-6098, 2017.

42. Vaccarino V: Ischemic heart disease in women: Many questions, few facts. Circ Cardiovasc Qual Outcomes 3: 111-115, 2010.

43. Pepine CJ, Balaban RS, Bonow RO, Diamond GA, Johnson BD, Johnson PA, Mosca L, Nissen SE and Pohost GM; National Heart, Lung and Blood Institute; American College of Cardiology Foundation: Women's Ischemic Syndrome Evaluation: Current status and future research directions: Report of the National Heart, Lung and Blood Institute workshop: October 2-4, 2002: Section 1: Diagnosis of stable ischemia and ischemic heart disease. Circulation 109: e44-e46, 2004.

44. Takasugi M, Hayakawa K, Arai D and Shiota K: Age- and sex-dependent DNA hypomethylation controlled by growth hormone in mouse liver. Mech Ageing Dev 134: 331-337, 2013.

45. Kwekel JC, Desai VG, Moland CL, Branham WS and Fuscoe JC: Age and sex dependent changes in liver gene expression during the life cycle of the rat. BMC Genomics 11: 675, 2010 
46. Jousilahti P, Vartiainen E, Tuomilehto J and Puska P: Sex, age, cardiovascular risk factors, and coronary heart disease: A prospective follow-up study of 14786 middle-aged men and women in Finland. Circulation 99: 1165-1172, 1999.

47. Jousilahti P, Vartiainen E, Tuomilehto J and Puska P: Twenty-year dynamics of serum cholesterol levels in the middle-aged population of eastern Finland. Ann Intern Med 125: 713-722, 1996.

48. Mendelsohn ME and Karas RH: Molecular and cellular basis of cardiovascular gender differences. Science 308: 1583-1587, 2005.

49. Bredfeldt TG, Greathouse KL, Safe SH, Hung MC, Bedford MT and Walker CL: Xenoestrogen-induced regulation of EZH2 and histone methylation via estrogen receptor signaling to PI3K/AKT. Mol Endocrinol 24: 993-1006, 2010

50. Kulig E, Landefeld TD and Lloyd RV: The effects of estrogen on prolactin gene methylation in normal and neoplastic rat pituitary tissues. Am J Pathol 140: 207-214, 1992.

51. Wiggins BS, Saseen JJ, Page RL II, Reed BN, Sneed K, Kostis JB, Lanfear D, Virani S and Morris PB; American Heart Association Clinical Pharmacology Committee of the Council on Clinical Cardiology; Council on Hypertension; Council on Quality of Care and Outcomes Research; and Council on Functional Genomics and Translational Biology: Recommendations for management of clinically significant drug-drug interactions with statins and select agents used in patients with cardiovascular disease: A scientific statement from the American Heart Association. Circulation 134: e468-e495, 2016.
52. Frishman WH: $\beta$-Adrenergic blockade in cardiovascular disease. J Cardiovasc Pharmacol Ther 18: 310-319, 2013.

53. Horinaka S: Use of nicorandil in cardiovascular disease and its optimization. Drugs 71: 1105-1119, 2011.

54. Ujhelyi MR, Ferguson RK and Vlasses PH: Angiotensin-converting enzyme inhibitors: Mechanistic controversies. Pharmacotherapy 9: 351-362, 1989.

55. Liu MZ, He FZ and Zhang W: Epigenetic research progress of anti-tumor drugs. Yao Xue Xue Bao 48: 1629-1636, 2013 (In Chinese).

56. Stone A, Valdés-Mora F, Gee JM, Farrow L, McClelland RA, Fiegl H, Dutkowski C, McCloy RA, Sutherland RL, Musgrove EA and Nicholson RI: Tamoxifen-induced epigenetic silencing of oestrogen-regulated genes in anti-hormone resistant breast cancer. PLoS One 7: e40466, 2012.

57. Baker EK, Johnstone RW, Zalcberg JR and El-Osta A: Epigenetic changes to the MDR 1 locus in response to chemotherapeutic drugs. Oncogene 24: 8061-8075, 2005.

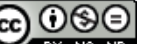

This work is licensed under a Creative Commons Attribution-NonCommercial-NoDerivatives 4.0 International (CC BY-NC-ND 4.0) License. 